\title{
SIMULATION OF THE RELATIONSHIP BETWEEN EXERCISE AND CARDIOPULMONARY FUNCTION AT HIGH ALTITUDE
}

\author{
SIMULAÇÃO DA RELAÇÃO ENTRE EXERCICIO E FUNÇÃO CARDIOPULMONAR EM GRANDES ALTITUDES \\ SIMULACIÓN DE LA RELACIÓN ENTRE EL EJERCICIO Y LA FUNCIÓN CARDIOPULMONARA GRAN ALTURA
}

Original Article

ARTIGO ORIGINAL

Artículo Original

Rui Li' ${ }^{\mathbb{D}}$
(Physical Education Professional)

1. Xi'an University of Finance and Economics, Shaan xi, Xi'an, China.

\section{Correspondence:}

Rui Li

Xi'an University of Finance and Economics, Shaan xi, Xi'an 710100, China. liruixaufe_01@126. comwenheqiong363@126.com

\begin{abstract}
Introduction: Due to various uncertain and unexpected factors in life such as diseases, natural disasters, traffic accidents, and congenital disabilities, the number and proportion of lower limb amputations are still rising for many reasons, so the research on lower limb prostheses is particularly important. Objective: This work aimed to study the relationship between altitude exercise and cardiopulmonary function. Methods: A model of abnormal changes in cardiopulmonary function was established, and then 40 plateau exercisers were selected, all of whom arrived in Tibet in March 2017. The relationship between pulmonary circulation volume and internal pressure in the chest was observed and compared. The relationship between cardiopulmonary sensory reflex and exercise (high altitude) breathing and heart rate was analyzed. A comparison of the cardiopulmonary function of subjects of different genders was implemented. Moreover, the influence of different altitudes on the subjects' cardiopulmonary function and the subjects' cardiopulmonary function changes before departure and during the first, second, and third week after departure were observed and compared. Results: I. As the pressure in the thoracic cavity increased, the subjects' pulmonary circulation blood volume gradually decreased, and the decrease was most obvious in the stage of thoracic pressure -50 to 0 . II. As the cardiorespiratory reflex coefficient increased, the subjects' breathing and heart rate compensatory acceleration appeared. III. Tracking and monitoring of the subjects' cardiopulmonary indicators revealed that with the increase in altitude, the subjects' average arterial pressure, respiratory frequency, and heart rate all showed an upward trend, while the blood oxygen saturation value showed a downward trend. IV. No matter how high the altitude was, the average arterial pressure, respiratory rate, and heart rate monitored of the subjects under exercise were significantly superior to the indicator values under resting state. In contrast, the blood oxygen saturation value showed the opposite trend. V. The subjects' average arterial pressure, respiration, and heart rate in the first week were higher than other periods, but the blood oxygen saturation was relatively lower. In the second and third weeks, the changes in cardiopulmonary function were relatively smooth (all $P<0.05)$. VI. The changes in the index of the cardiopulmonary function of subjects of different genders were small ( $p>0.05$ ). Conclusion: Through modeling, the results of the plateau environment on the cardiopulmonary function of the body were made clearer, and these research data provided theoretical references for the training of the sports field in the plateau area. Level of evidence ll; Therapeutic studies - investigation of treatment results.
\end{abstract}

Keywords: Cardiopulmonary function; Altitude; Exercise test; Exercise.

\section{RESUMO}

Contexto: devido a vários fatores incertos e inesperados da vida, como doenças, desastres naturais, acidentes de trânsito e defeitos congênitos, o número e a proporção de amputações de membros inferiores ainda estão aumentando por muitos motivos, portanto, a pesquisa sobre próteses de membros inferiores é particularmente importante. Objetivo: Este trabalho teve como objetivo estudar a relação entre o exercício em altitude e a função cardiopulmonar. Métodos: Um modelo de alterações anormais da função cardiopulmonar foi estabelecido e, em seguida, 40 praticantes de exercícios de platô foram selecionados, todos chegaram ao Tibete em março de 2017. A relação entre o volume de circulação pulmonar e a pressão interna no tórax foi observada e comparada. A relação entre o reflexo sensorial cardiopulmonare a respiração do exercício (altitude) e a frequência cardíaca foi analisada. A comparação da função cardiopulmonar de individuos de diferentes gêneros foi implementada. Além disso, a influência de diferentes altitudes na função cardiopulmonar dos individuos e as mudanças na função cardiopulmonar dos indivíduos antes da partida e durante a primeira, segunda e terceira semanas após a partida foram observadas e comparadas. Resultados: I. À medida que a pressão na cavidade torácica aumentou, o volume de sangue da circulação pulmonar dos indivíduos diminuiu gradualmente, e a diminuição foi mais óbvia no estágio de pressão torácica -50 a 0. II. À medida que o coeficiente do reflexo cardiorrespiratório aumentou, a respiração dos indivíduos e a aceleração compensatória da frequência cardíaca apareceram. III. O rastreamento e o monitoramento dos indicadores cardiopulmonares dos indivíduos revelaram que, com o aumento da altitude, a pressão arterial média, a frequência respiratória e a frequência cardíaca dos indivíduos mostraram uma tendência ascendente, enquanto o valor de saturação de oxigênio no sangue mostrou uma tendência descendente. 4. Por mais alta que fosse a altitude, a pressão arterial média, a frequência respiratória e a frequência cardíaca monitoradas dos indivíduos em exercício foram significativamente superiores aos valores do indicador em repouso, enquanto o valor da saturação de oxigênio no sangue apresentou tendência oposta. V. A pressão arterial média, respiração e frequência cardíaca dos indivíduos na primeira semana foram maiores 
do que em outros períodos de tempo, mas a saturação de oxigênio no sangue foi relativamente menor. Na segunda e terceira semanas, as mudanças na função cardiopulmonar foram relativamente suaves (todos $P<0,05$ ). VI. As mudanças no índice de função cardiopulmonar de sujeitos de diferentes gêneros foram pequenas $(p>0,05)$. Conclusão: Por meio da modelagem, os resultados do ambiente de planalto sobre a função cardiopulmonar do corpo ficaram mais claros, e os dados dessas pesquisas forneceram referenciais teóricos para o treinamento do campo esportivo na área de planalto. Nível de evidência ll; Estudos terapêuticos-investigação dos resultados do tratamento.

Descritores: Função cardiopulmonar; Altitude; Teste de esforço; Exercício físico.

\section{RESUMEN}

Antecedentes: debido a varios factores inciertos e inesperados en la vida, como enfermedades, desastres naturales, accidentes de tráfico y defectos de nacimiento, el número y la proporción de amputaciones de miembros inferiores sigue aumentando por muchas razones, por lo que la investigación sobre prótesis de miembros inferiores es particularmente importante. Objetivo: Este trabajo tuvo como objetivo estudiar la relación entre el ejercicio de altura y la función cardiopulmonar. Métodos: Se estableció un modelo de cambios anormales en la función cardiopulmonar y luego se seleccionaron 40 deportistas meseta, todos los cuales llegaron al Tíbet en marzo de 2017. Se observó y comparó la relación entre el volumen de circulación pulmonar y la presión interna en el tórax. Se analizó la relación entre el reflejo sensorial cardiopulmonar y la respiración durante el ejercicio (a gran altitud) y la frecuencia cardíaca. Se implementó la comparación de la función cardiopulmonar de sujetos de diferentes géneros. Además, se observó y comparó la influencia de las diferentes altitudes en la función cardiopulmonar de los sujetos y los cambios de la función cardiopulmonar de los sujetos antes de la partida y durante la primera, segunda y tercera semana después de la partida. Resultados: I. A medida que aumentó la presión en la cavidad torácica, el volumen sanguíneo de la circulación pulmonar de los sujetos disminuyó gradualmente y la disminución fue más obvia en la etapa de presión torácica -50 a 0. II. A medida que aumentaba el coeficiente de reflejo cardiorrespiratorio, apareció la aceleración compensadora de la frecuencia cardíaca y la respiración de los sujetos. III. El seguimiento y monitoreo de los indicadores cardiopulmonares de los sujetos revelaron que con el aumento de altitud, la presión arterial promedio, la frecuencia respiratoria y la frecuencia cardíaca promedio de los sujetos mostraron una tendencia ascendente, mientras que el valor de saturación de oxígeno en sangre mostró una tendencia descendente. IV. No importa qué tan alta sea la altitud, la presión arterial, la frecuencia respiratoria y la frecuencia cardiaca promedio monitoreadas de los sujetos en ejercicio fueron significativamente superiores a los valores del indicador en estado de reposo, mientras que el valor de saturación de oxígeno en sangre mostró la tendencia opuesta. V. La presión arterial, la respiración y la frecuencia cardíaca promedio de los sujetos en la primera semana fueron más altas que en otros períodos de tiempo, pero la saturación de oxígeno en sangre fue relativamente más baja. En la segunda y tercera semanas, los cambios en la función cardiopulmonar fueron relativamente suaves (todos $P<0,05$ ). VI. Los cambios en el índice de función cardiopulmonar de sujetos de diferentes géneros fueron pequeños ( $p>0.05$ ). Conclusión: A través de la modelización, se aclararon los resultados del ambiente de meseta sobre la función cardiopulmonar del cuerpo, y estos datos de investigación proporcionaron referencias teóricas para el entrenamiento del campo deportivo en el área de meseta.

\section{Nivel de evidencia ll; Estudios terapéuticos- investigación de los resultados del tratamiento.}

Descriptores: Función cardiopulmonar; Altitud; Ambiente hipóxico; Prueba de esfuerzo; Ejercicio físico.

\section{INTRODUCTION}

Altitude exercise refers to exercise in areas above 500 meters above sea level. The plateau terrain is relatively flat, and there are large undulating areas. Due to its high altitude, low air pressure, and low oxygen content, this special environment is more conducive to improving people's physical strength and endurance quality, so as to help athletes maximize their inner potential. ${ }^{1,2}$

Exercising in a plateau environment has the greatest impact on the exerciser's cardiopulmonary function, and the improvement of the athlete's physical fitness depends to a high degree on the improvement of the cardiopulmonary function. It can provide a reliable theoretical basis for exercisers by analyzing the relationship between the them. ${ }^{3}$

In previous studies, it was found that most researchers performed statistical analysis on the physiological response results of exercisers under altitude exercise without establishing a model, making the research results more limited. The emergence of an analysis model of abnormal interaction changes that can consider cardiopulmonary function parameters made this research enter a more specialized level. 4,5 Therefore, an analysis model of abnormal changes in the interaction of cardiopulmonary function was established in this research, and 40 plateau exercisers were selected as the research object. A simulation study on the relationship between altitude exercise and cardiopulmonary function was carried out, aiming to provide a reference for the sports world or subsequent research. The following reports were made.

\section{METHODS}

\section{Principles of modeling the relationship between altitude exercise and cardiopulmonary function}

The most important part of establishing the relationship model between altitude exercise and cardiopulmonary function was the setting of physiological parameters, which mainly referred to the parameters of cardiopulmonary function. Among the cardiopulmonary function parameters, the important indicators included cardiopulmonary oxygen uptake $\left(\mathrm{PO}_{2}\right)$, carbon dioxide emissions $\left(\mathrm{PCO}_{2}\right)$, and heart rate $(\mathrm{HR})$. In 
addition, there are ventilation volume per unit time $(\mathrm{Pa})$, oxygen pulse $\left(\mathrm{O}_{2} \mathrm{P}\right)$, etc. The calculation equations were as follows.

Maximal oxygen uptake:

$P o_{2} \max =H R \max * M N * L T$

Cardiopulmonary oxygen uptake:

$P o_{2}=H R * L T * M N$

Oxygen pulse:

$$
O_{2} P=L T * M N
$$

$M N$ represents the output of each pulse, and $L T$ represents the difference in oxygen content between arteries and veins. Oxygen pulse can measure the athlete's ventricular function.

Maximum heart rate:

$$
H R \max =220-\text { age }
$$

Studies believed that the person's age had the greatest impact on heart rate.

Athlete's breathing entropy in altitude sports:

$$
S Y=\frac{P o_{2}}{P \mathrm{Po}_{2}}
$$

Respiration entropy expresses the oxygen exchange rate of athletes during breathing.

\section{Model of abnormal changes in cardiopulmonary function interaction}

When athletes exercise in the plateau area, their heart and lung excitement is much higher than that in the plain area. Usually, the excitement of the heart and lung receptors will reduce the tension of the foot shaft, while the tension of vagus nerve of the heart will increase, reducing the heart rate and blood pressure. The relationship between intrathoracic pressure and cardiopulmonary receptors can be described by the following equation.

$$
\frac{q n_{1}}{q l}=\frac{n_{1}}{l_{1}}+r\left(\frac{d_{h}-d^{0}{ }_{h}}{d_{h}^{0}}\right)
$$

$n_{1}$ represents cardiopulmonary sensory reflex exercise, $I$, represents the coefficient of sensory transmission, and $r$ represents the enhancement coefficient of sensory reflex, which is related to the breathing intensity during exercise. The baroreflex produced by lung breathing movement can be expressed by the following equation.

$$
\mathrm{W}=\mathrm{Wr}+0.25 * \mathrm{We}
$$

W represents the sensory pressure value, $W r$ represents the average carotid artery pulse pressure, and We represents the carotid artery pulse pressure.

\section{Research objects}

40 plateau athletes were selected, all of which arrived in Tibet in March 2017. Among them, there were 21 males and 19 females; aged 27 to 36 years old, with an average of (31.32 \pm 1.93$)$ years old; average body weight $(62 \pm 7) \mathrm{kg}$. The occupations of the included persons were all ordinary employees, they had no history of plateau tourism in the past six months, and didn't perform strong physical labor. They had no previous history of cardiopulmonary diseases, no infectious diseases, neurological diseases, etc., The physical examination indicators before being included in the study were all normal. The exercise route of all research objects was Lhasa-Nyingchi area (2000m above sea level).

\section{Research methods}

Giving the difficulty of collecting specimens in plateau areas, not every subject adopted the method of non-invasive detection method. The monitored indicators included heart rate, blood pressure, respiration, and blood oxygen saturation.

\section{Observation indicators}

I. The relationship between pulmonary circulation volume and the internal pressure of the chest.

II. The relationship between cardiopulmonary sensory reflex and exercise (high altitude) breathing and heart rate.

III. Cardiopulmonary function comparison of subjects of different genders, including mean arterial pressure, respiration, pulse, and blood oxygen saturation.

IV. The effects of different altitudes on the subjects' cardiopulmonary function, including mean arterial pressure, blood oxygen saturation, heart rate, and respiration.

$V$. The subjects' cardiopulmonary function changes before departure and the first, second, and third weeks after departure. All were monitored at 8:00 in the morning.

\section{Statistical methods}

SPSS 21.0 version software was employed for data analysis, and $P<0.05$ was deemed as statistically significant. ( $\bar{x} \pm s$ ) was how measurement data were expressed, which were tested by $t$ test.

\section{RESULTS}

\section{The relationship between pulmonary circulation volume and intrathoracic pressure}

Statistics showed that with the increase of intrathoracic pressure, the subjects' pulmonary circulation blood volume gradually decreased, and the decrease in thoracic pressure -50 to 0 was the most obvious, with considerable differences $(p<0.05)$ (Figure 1).

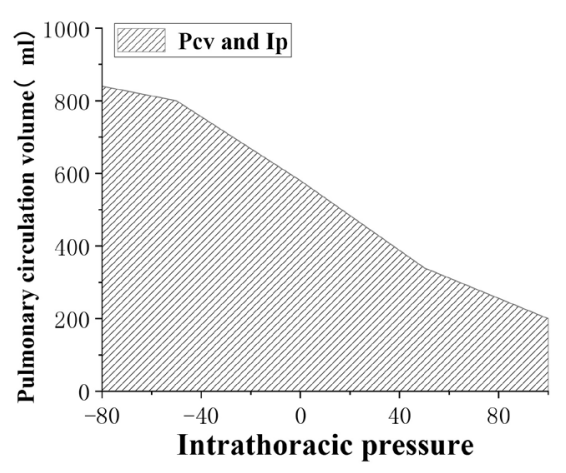

Figure 1. The relationship between pulmonary circulation volume and intrathoracic pressure. 
The relationship between cardiorespiratory reflex and exercise (high altitude) breathing and heart rate

According to statistics, with the increase of the cardiorespiratory reflex coefficient, the subjects' respiration and heart rate compensatory acceleration appeared, the difference was statistically substantial $(p<0.05)$ (Figure 2).

\section{Cardiopulmonary function comparison of subjects of diffe- rent genders}

According to statistics, the changes in the indicators of cardiopulmonary function of subjects of different genders were small, and the difference wasn't obvious ( $p>0.05$ ) (Figure 3).

\section{The influence of different altitudes on the subjects' cardio- pulmonary function}

According to statistics, no matter how high the altitude was, the average arterial pressure, respiratory rate, and heart rate monitored of the subjects under exercise were notably higher than the indicator values under resting state, while the blood oxygen saturation value showed the opposite trend. With the increase in altitude, the subjects' average arterial pressure, respiratory rate, and heart rate all showed an increasing trend, while the blood oxygen saturation value showed a decreasing trend, with substantial differences $(p<0.05)$ (Figure 4-6).

\section{The subjects' cardiopulmonary function changes before de-} parture and at first, second, and third week after departure

According to statistics, the average arterial pressure, respiration, and heart rate of the subjects in the first week were higher than those of other time periods, but the blood oxygen saturation was relatively lower. The changes in cardiopulmonary function in the second and third weeks were relatively gentle, and all the differences were remarkable $(p<0.05)$ (Figure 7).

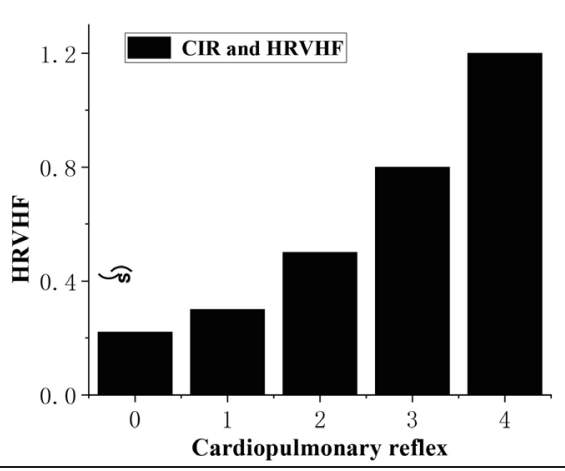

Figure 2. The relationship between cardiopulmonary sensory reflex and exercise (high altitude) breathing and heart rate.

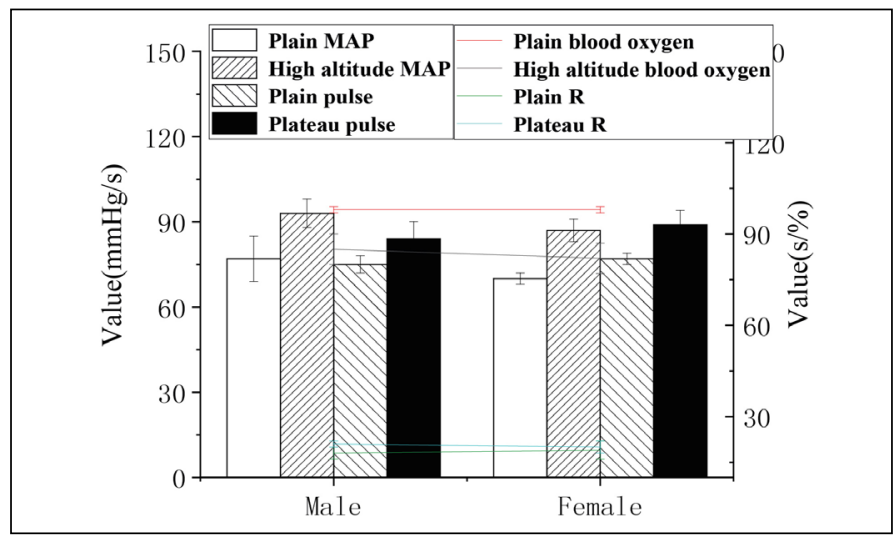

Figure 3. Cardiopulmonary function comparison of subjects of different genders.

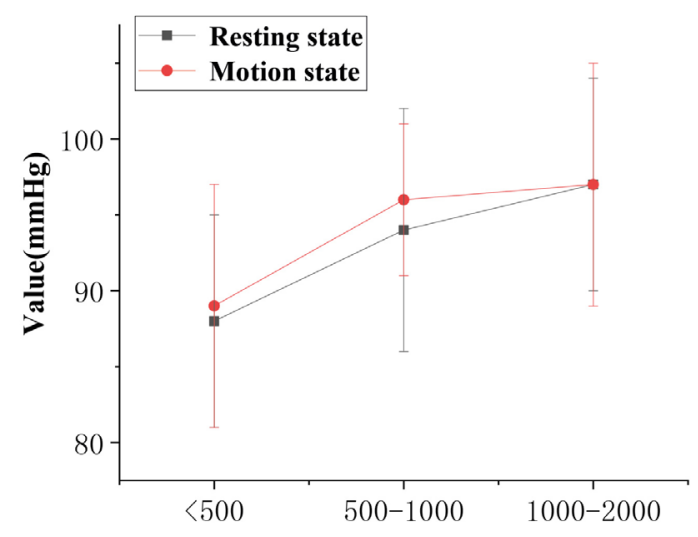

Figure 4. Mean arterial pressure of subjects at different altitudes.

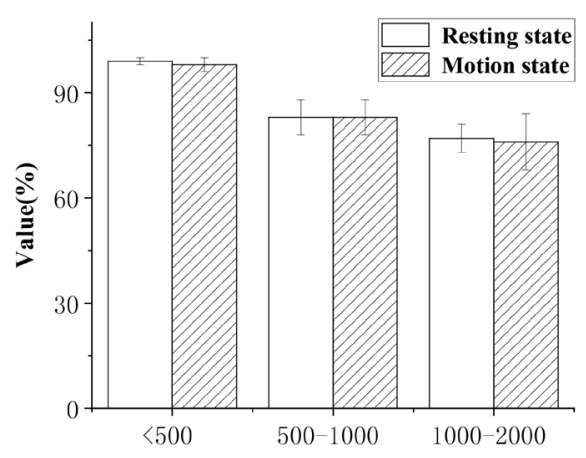

Figure 5. Blood oxygen saturation of subjects at different altitudes.

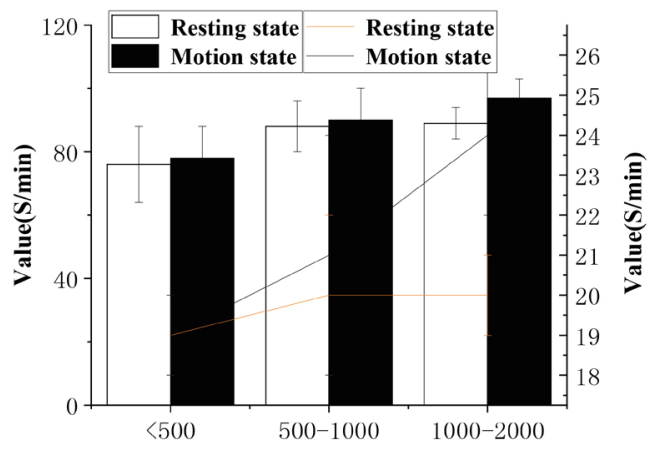

Figure 6. Heart rate and respiration of subjects at different altitudes.

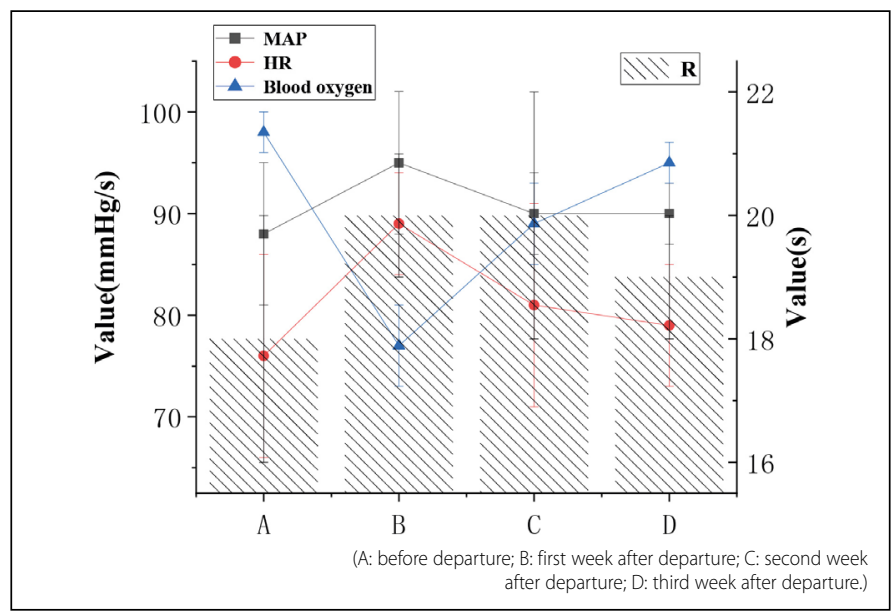

Figure 7. Changes in the cardiopulmonary function of subjects at different times. 


\section{DISCUSSION}

After the athletes in the plain area enter the high-altitude area for a short time, the body will inevitably undergo a series of changes in order to adapt to the low oxygen environment. 6 The human body's response to altitude hypoxia begins with changes in the respiratory and circulatory systems. ${ }^{7}$ In this research, the plateau area and the heart and lung changes were studied through modeling. The traditional cardiopulmonary parameter analysis model must require the parameters to be stable without abnormal changes. Once the parameters change irregularly, the modeling process can't be completed effectively. ${ }^{8}$ Therefore, a model of interactive abnormal changes in cardiopulmonary function was adopted in this work. The results showed that with the increase of intrathoracic pressure, the subjects' pulmonary circulation blood volume gradually decreased, and the decline was most obvious in the stage of thoracic pressure -50 to 0 . As the cardiorespiratory reflex coefficient increased, the subjects' breathing and heart rate compensatory acceleration appeared. It reflected the relatively intuitive impact of the low-oxygen environment in the plateau area on subjects, which was similar to the results of related researchers. ${ }^{9}$

The hypoxic environment in the plateau area can directly trigger the compensatory excitatory response of the cardiopulmonary. Mean arterial pressure, respiratory rate, heart rate, and blood oxygen saturation are the first to undergo compensatory changes. ${ }^{10}$ According to the above research results, with the increase in altitude, the average arterial pressure, respiratory rate, and heart rate of the subjects all increased, while the blood oxygen saturation value decreased. It was caused by physiological changes in the arteries and blood vessels of the heart and lungs. In plateau areas, the human cardiopulmonary nerve receptors are stimulated by strong mechanical stimulation in the thoracic cavity. Moreover, as the altitude increases, respiratory exercise will cause changes in the blood volume and pressure of the heart and lungs, and the stimulation of the heart and lung receptors will increase, leading to increased heart rate variability. In addition, it was also found that the indicators of cardiopulmonary function of subjects of different genders changed little.

\section{CONCLUSION}

The model further analyzed the influence of exercise under the plateau environment on the body's heart and lung function. The simulation results showed that as the pressure in the chest cavity increased, the subjects' pulmonary circulation blood volume gradually decreased. The most obvious decrease in chest pressure was from -50 to 0. Moreover, as the cardiorespiratory reflex coefficient increased, the subjects'breathing and heart rate compensatory speeded up. The tracking and monitoring of the subjects' cardiopulmonary indicators found that with the increase in altitude, the subjects' average arterial pressure, respiratory rate, and heart rate all increased, while the blood oxygen saturation value decreased.

The author declare no potential conflict of interest related to this article

AUTHORS' CONTRIBUTIONS: Rui Li established a model of abnormal changes in cardiopulmonary function and analyzed the influence of exercise under the plateau environment on the body's heart and lung function.

\section{REFERENCES}

1. Hebisz P, Hebisz R, Borkowski J, Zatoń M. Time of VO(2)max plateau and post-exercise oxygen consumption during incremental exercise testing in young mountain bike and road cyclists. Physiol Res. 2018;67(5):711-9.

2. Moore DR, Robinson MJ, Fry JL, Tang JE, Glover El, Wilkinson SB, Prior T, Tarnopolsky MA, Phillips SM. Ingested protein dose response of muscle and albumin protein synthesis after resistance exercise in young men. Am J Clin Nutr. 2009;89(1):161-8.

3. Kraus TM, Martetschläger F, Müller D, Braun KF, Ahrens P, Siebenlist S, Stöckle U, Sandmann GH. Return to sports activity after tibial plateau fractures: 89 cases with minimum 24-month follow-up. Am J Sports Med. 2012;40(12):2845-52.

4. Bernholt DL, DePhillipo NN, Grantham WJ, Crawford MD, Aman ZS, et al. Morphologic Variants of Posterolateral Tibial Plateau Impaction Fractures in the Setting of Primary Anterior Cruciate Ligament Tear. Am J Sports Med. 2020;48(2):318-25

5. Zann GJ, Kim SE, Tinga S, Pozzi A, Banks SA. The effect of tibial plateau leveling osteotomy on patellofemoral kinematics in dogs: An in vivo study. Vet Surg. 2020 Jan;49(1):207-213.
6. Marsh CE. Validity of oxygen uptake cut-off criteria in plateau identification during horizontal treadmill running. J Sports Med Phys Fitness. 2019;59(1):10-16.

7. Schöffl I, Ehrlich B, Stanger S, Rottermann K, Dittrich S, Schöffl V. Exercise field testing in children: a new approach for age-appropriate evaluation of cardiopulmonary function. Pediatr Cardiol. 2020;41(6):1099-106

8. Heine M, Hoogervorst EL, Hacking HG, Verschuren O, Kwakkel G. Validity of maximal exercise testing in people with multiple sclerosis and low to moderate levels of disability. Phys Ther. 2014;94(8):1 168-75

9. Oliver N, Onofre T, Carlos R, Barbosa J, Godoy E, Pereira E, Guerra RO, Bruno S. Ventilatory and Metabolic Response in the Incremental Shuttle and 6-Min Walking Tests Measured by Telemetry in Obese Patients Prior to Bariatric Surgery. Obes Surg. 2015;25(9):1658-65.

10. Díaz O, Morales A, Osses R, Klaassen J, Lisboa C, Saldías F. [Six-minute-walk test and maximum exercise test in cycloergometer in chronic obstructive pulmonary disease. Are the physiological demands equivalent?]. Arch Bronconeumol. 2010;46(6):294-301. Spanish. 